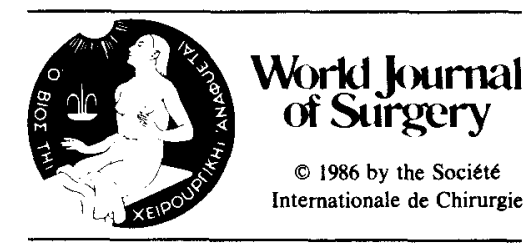

\title{
Primary Hyperaldosteronism Caused by Adrenocortical Carcinoma
}

\author{
H. William Scott, Jr., M.D., Craig R. Sussman, M.D., David L. Page, M.D., \\ Norman W. Thompson, M.D., Milton D. Gross, M.D., and Ricardo Lloyd, M.D. \\ Departments of Surgery, Pathology, and Nuclear Medicine, Vanderbilt University, Nashville, Tennessee, \\ and the University of Michigan, Ann Arbor, Michigan, U.S.A.
}

\begin{abstract}
Since the syndrome of primary hyperaldosteronism was described by Jerome Conn in 1955 , over 300 patients with this disorder have been identified in the medical centers of Vanderbilt University and the University of Michigan. The most frequent cause of this endocrinopathy has been a solitary adenoma of the adrenal cortex (72\%); bilateral adrenocortical hyperplasia has been the cause of primary hyperaldosteronism in $27 \%$ of cases; less frequently, the cause has been multiple and/or bilateral adenomas $(1 \%)$.

During the last 4 years in these 2 medical centers, we have encountered 3 patients who have had biochemically proven primary hyperaldosteronism due to adrenocortical carcinoma. Each of these unusual cases is summarized with review of the recent literature.
\end{abstract}

Since the syndrome of primary hyperaldosteronism was described by Jerome Conn [1] of the University of Michigan in 1955, there has been a large experience throughout the world with this curable cause of hypertension. In the last 3 decades, over 300 patients with this disorder have been identified and studied in the medical centers of Vanderbilt University and the University of Michigan. The most frequent cause of Conn's syndrome has been a solitary adenoma of the adrenal cortex $(72 \%)$; bilateral adrenocortical hyperplasia has been the cause of primary hyperaldosteronism in $27 \%$ of cases; less frequently, the cause has been multiple and/or bilateral adrenocortical adenomas (1\%) (Table 1). During the last 4 years in these 2 medical centers,

Presented at the International Association of Endocrine Surgeons in Paris, September 1985.

Reprint requests: H. William Scott, Jr., M.D., Vanderbilt University Medical Center, Nashville, Tennessee 37232 , U.S.A. we have encountered 3 patients who had biochemically proven primary hyperaldosteronism caused by adrenocortical carcinoma. Details of these 3 patients are summarized.

\section{Case Reports}

Case 1

This 41-year-old white male had enjoyed good health until December, 1981, when he noted blurring of vision in his right eye. He consulted an ophthalmologist who found retinal hemorrhages and early bilateral choked disks; the patient's blood pressure was $270 / 140$. His local physician confirmed the hypertension and started him on Inderal ${ }^{\circledR}$ and Lasix $^{\circledR}$. After a few days of this therapy his serum potassium level fell from an initial $2.2 \mathrm{mEq} / \mathrm{l}$ to 1.9 $\mathrm{mEq} / \mathrm{l}$. He was promptly admitted to a local hospital where stimulated plasma renin activity was less than $0.1 \mathrm{ng} / \mathrm{ml}$ per $\mathrm{hr}$ with a plasma aldosterone level of $86 \mathrm{ng} / 100 \mathrm{ml}$. A computed tomography (CT) scan of the abdomen showed a $6 \times 8 \mathrm{~cm}$ left adrenal mass with areas of nonhomogeneity. A diagnosis of primary hyperaldosteronism was made. Antihypertensive drugs included Inderal ${ }^{\circledR}$, Aldactone ${ }^{\circledR}$, Lasix $^{\circledR}$, and Apresoline ${ }^{\circledR}$ with potassium supplementation as initial therapy.

On transfer to Vanderbilt University Hospital, his blood pressure was 145/95 and his physical examination was otherwise normal except for ocular findings of grade II hypertensive changes. Laboratory studies showed serum sodium $144 \mathrm{mEq} / \mathrm{l}$, potassium $4.8 \mathrm{mEq} / \mathrm{l}$; serum chloride, bicarbonate, glucose, and creatinine were also normal on admission.

After discontinuance of diuretics and Aldactone ${ }^{\circledR}$, his serum potassium fell to levels less than $3 \mathrm{mEq} / \mathrm{l}$ 
Table 1. Causes of primary hyperaldosteronism in more than 300 patients.

\begin{tabular}{lr} 
& $\%$ \\
\hline Solitary adrenal adenoma & 72 \\
Bilateral cortical hyperplasia & 27 \\
Multiple bilateral adenomas & 1
\end{tabular}

with an increased urinary excretion of potassium in the range of $50 \mathrm{mEq} / 24 \mathrm{hr}$. Cortisol, catecholamines, and metabolites were normal in plasma and urine. A saline suppression test (1.5 liters normal saline intravenously infused in $2 \frac{1}{2} \mathrm{hr}$ ) showed baseline plasma aldosterone of $41 \mathrm{ng} / 100 \mathrm{ml}$ and 36 $\mathrm{ng} / 100 \mathrm{ml}$ at the end of the infusion; supine and upright plasma renin levels were undetectable. The diagnosis of primary hyperaldosteronism was confirmed.

On March 29, 1982, exploration of the adrenals was carried out using a left thoracoabdominal approach. The right adrenal was normal. The left adrenal was replaced by an encapsulated mass $8 \times$ $7 \times 8 \mathrm{~cm}$ in size. There were no hepatic or lymph node metastases. Lateral attachments of the spleen were divided and the spleen reflected toward the midline. After Gerota's fascia was incised, the upper pole of the kidney could be dissected free from the suprarenal tumor and depressed. The adrenal arteries and the enlarged adrenal vein were ligated and divided; the encapsulated tumor was mobilized circumferentially and totally removed (Fig. 1).

Early postoperative recovery was uncomplicated. Serum potassium levels remained in the normal range but a mild hypertension persisted. The wound healed without infection.

The adrenal tumor measured $8 \mathrm{~cm}$ in largest dimension and weighed $180 \mathrm{~g}$ on pathologic examination. Perhaps $80 \%$ of the tumor mass consisted of blood which was most often liquid and occasionally solid (Fig. 2). Histologically identifiable neoplasm was present within the entire thickened fibrous capsule and measured only $2-5 \mathrm{~mm}$ in thickness at any point. There was also some tumor adjacent to clotted blood centrally. Much of the tumor had a broad trabecular pattern histologically as described by Symington [2] in malignant aldosterone-producing tumors. The nucleoli were large and hyperchromatic in many areas, and rare mitoses were apparent. Focally, there was capsular invasion (Fig. 3).

A diagnosis of adrenal cortical carcinoma was made. Because of mild diastolic hypertension, the patient was placed on Inderal ${ }^{\circledR} 80 \mathrm{mg} 4$ times a day and Lasix ${ }^{\circledR} 40 \mathrm{mg}$ daily with potassium supplements. Serum potassium, aldosterone, cortisol, and renin levels were normal after the operation. He was discharged on April 6, 1982.

During the last $31 / 2$ years, his blood pressure has been in the 130-140 over 90-95 range on hydrochlorothiazide $50 \mathrm{mg}$ daily. Repeated serum aldosterone, renin, and potassium levels have been normal and with no evident recurrence of tumor.

\section{Case 2}

This 42-year-old white male veteran was first seen and treated in Ann Arbor in August, 1982, because of recurrent episodes of syncope in the prior 6 months. He gave a history of mild hypertension of a possible 20 years' duration. In the preceding 4 years he had intermittent chest pain and was evaluated for possible myocardial infarction, but this was excluded. Two years before admission his hypertension became more severe and more difficult to manage. Medications included Aldomet $\$ 250 \mathrm{mg}$ twice per day and hydrochlorothiazide $50 \mathrm{mg}$ every day. Despite the drug therapy, his blood pressure was $170 / 100$ on admission. Past history indicated no significant illness other than hypertension.

His findings of significance included left axis deviation on electrocardiograph and a serum potassium level of $2.3 \mathrm{mEq} / \mathrm{l}$. After an extensive evaluation, it was concluded that his syncopal spells were due to arrhythmias and the hypokalemia was caused by diuretics. His potassium deficit was replaced and at discharge his serum potassium level was $4.0 \mathrm{mEq} / \mathrm{l}$ or higher. He was sent home on Aldomet ${ }^{\circledR}$ and hydrochlorothiazide with potassium supplementation.

His second admission to the hospital was in April, 1983, at age 43, because of intermittent claudication of 1 year's duration. At that time he was hypertensive (blood pressure 180/110) while on Lopressor $^{\circledR} 150 \mathrm{mg}$ twice a day, hydralazine $50 \mathrm{mg}$ twice a day, Moduretic ${ }^{\circledR} 1$ tablet daily, and potassium chloride $20 \mathrm{mEq}$ twice a day. His serum potassium level on admission was $2.6 \mathrm{mEq} / \mathrm{l}$. Peripheral vascular evaluation showed minimal evidence of atherosclerotic occlusive disease in the lower leg arteries thought not to be of surgical significance.

Because of his progressive drug-resistant hypertension and persistent hypokalemia, a third-year medical student urged that a complete work-up for primary aldosteronism be initiated. The following studies were done to confirm the clinical impression of primary aldosteronism. Urinary aldosterone levels on 2 occasions were 35 and $36 \mathrm{mcg} / 24 \mathrm{hr}$ (normal 4-20); renin (radioimmunoassay) was $0.3 \mathrm{ng} / \mathrm{ml}$ per hr (normal $0.5-2.0 \mathrm{ng} / \mathrm{ml}$ per $\mathrm{hr}$ ). Serum cortisol (A.M.) was $11.6 \mathrm{mcg} / 100 \mathrm{ml}$ (in normal range); 

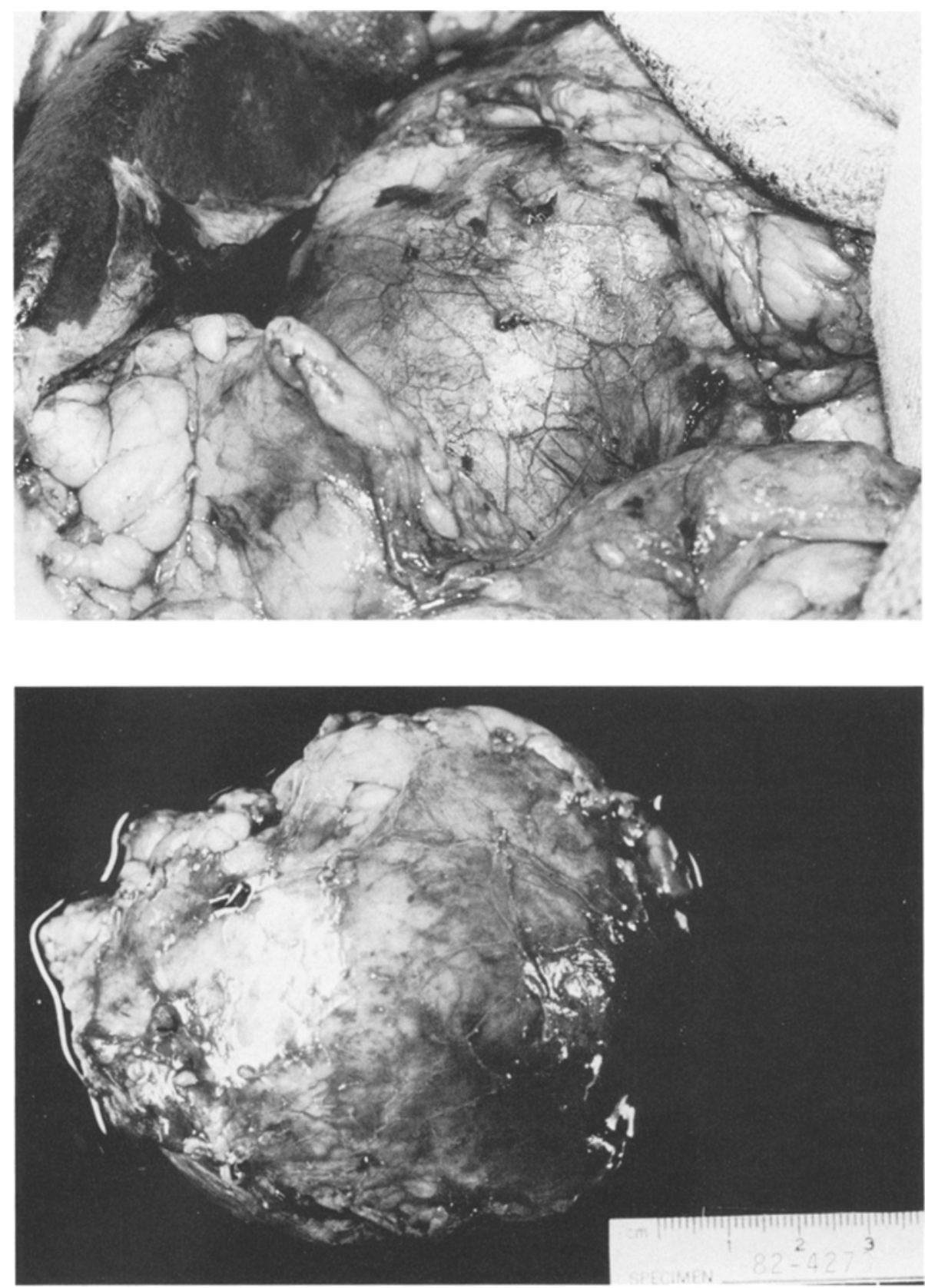

Fig. 1. Patient 1: Left thoracoabdominal exposure of encapsulated left adrenal tumor at operation. Spleen has been mobilized and reflected down and to patient's right.
Fig. 2. Patient 1: Excised $8 \times$ $7 \times 8 \mathrm{~cm}$ left adrenal tumor weighed $180 \mathrm{~g}$. serum aldosterone level was $24 \mathrm{ng} / 100 \mathrm{ml}$ (normal $3-10)$.

A renal arterial angiogram showed normal renal arteries. Before serum potassium was replaced, levels ranged from 2.4 to $2.6 \mathrm{mEq} / \mathrm{l}$. Urinary catecholamines during 24-hr collections were normal on 2 occasions. An abdominal CT scan on May 24, 1983 , showed a $4 \times 4 \times 5 \mathrm{~cm}$ encapsulated mass in the region of the right adrenal. After preparation with dexamethasone for 7 days, an NP-59 scan was done on June 10, 1983. Five days after injection of the isotope there was intense uptake by the right adrenal mass but no activity on the left side.
After preparation with spironolactone and replacement of potassium deficits, the patient was submitted to exploration of the right adrenal mass via a posterior approach through the bed of the resected 11th rib. An encapsulated adrenal tumor measuring $7 \times 7 \times 3 \mathrm{~cm}$ in size was resected. A wound cellulitis developed in the postoperative period but was controlled by antibiotics. Otherwise, the patient made an uncomplicated recovery.

The neoplasm weighed $60 \mathrm{~g}$ on pathologic examination and had a predominance of cells compartmentalized into small and large groups with mostly clear cytoplasm and occasional compact cells. 

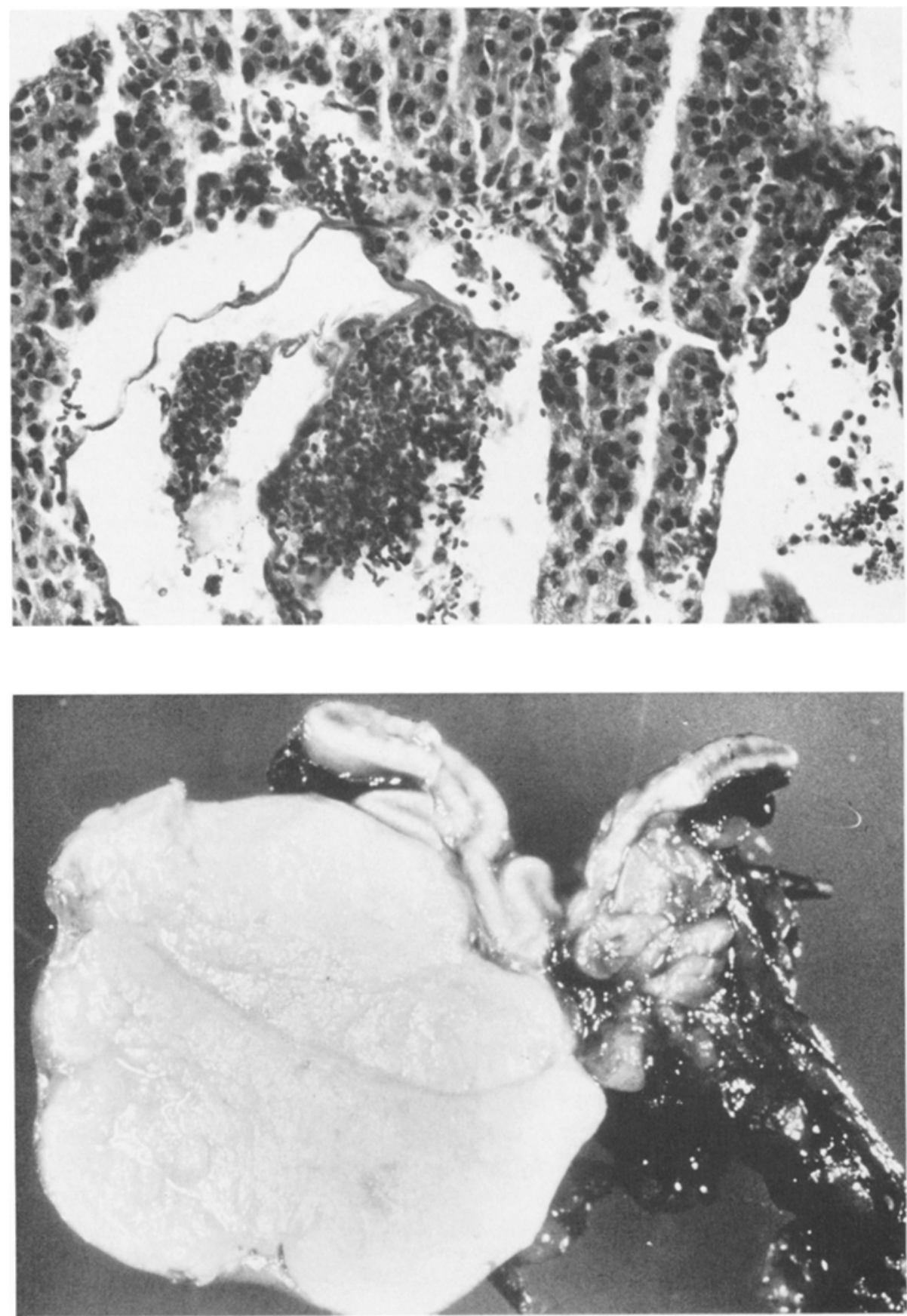

Fig. 3. Patient 1:

Photomicrograph of adrenal tumor showing trabecular pattern as described by Symington in malignant aldosterone-producing adrenal tumors.
Fig. 4. Patient 2: Excised $7 \times 7$ $\times 3 \mathrm{~cm}$ right adrenal tumor weighed $60 \mathrm{~g}$.
There were focal areas where mitoses were present and microscopic capsular invasion was seen (Fig. 4).

A diagnosis of adrenal cortical carcinoma was made. After operation, the patient was maintained on hydrocortisone and Florinef ${ }^{\circledR}$. An abdominal and chest CT scan showed no evidence of intra-abdominal, hepatic, or pulmonary metastases. The patient was started on mitotane therapy, $3 \mathrm{~g}$ per day. At discharge in July, 1983, his blood pressure was normal without antihypertensive drugs; the serum sodium level was $136 \mathrm{mEq} / \mathrm{l}$ and potassium 4.0 $\mathrm{mEq} / \mathrm{l}$.

During the 2 years of follow-up, his blood pressure has been in the range of $120-130$ over 80 and his serum potassium level has been normal. One year after the operation, his serum aldosterone level was normal as was his urinary aldosterone concentration. On his most recent evaluation in July, 1985, these normal findings in blood pressure, potassium, and aldosterone persisted and he had no evidence of recurrent adrenal carcinoma. 


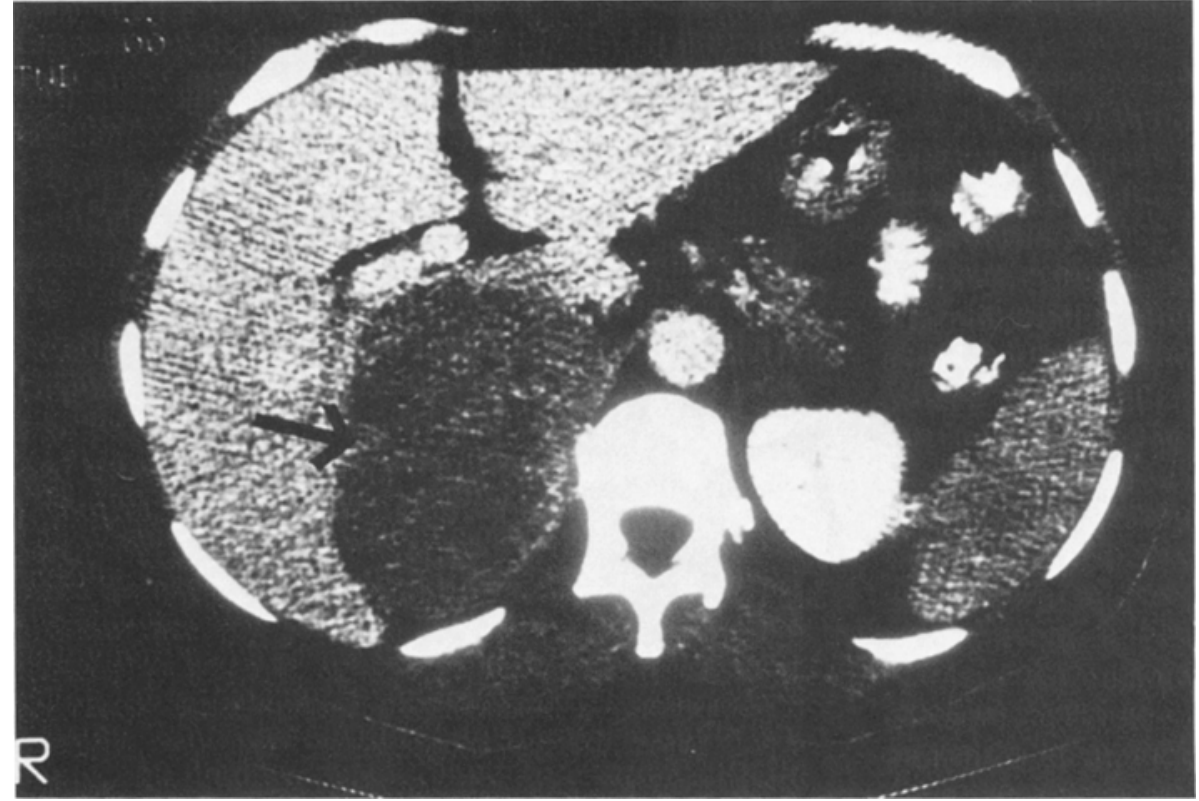

Fig. 5. Patient 3: Computed tomography scan of upper abdomen shows $11 \times 10 \times 7$ $\mathrm{cm}$ right adrenal mass that is solid but not homogeneous.

\section{Case 3}

This 54-year-old white female was admitted to the University of Michigan Hospital December 14, 1984, with a diagnosis of possible primary hyperaldosteronism. She had enjoyed good health until the summer of 1984 when she developed headaches and episodes of "light headedness." In November, 1984, her family physician found her blood pressure to be 200/94. A few days later blood pressure was 250/120 and her serum potassium level was $3.0 \mathrm{mEq} / \mathrm{l}$; serum sodium was $149 \mathrm{mEq} / \mathrm{l}$. She was not taking diuretics. Based on these findings, her family physician immediately suspected that she had primary hyperaldosteronism.

On admission to her local hospital in December, 1984, her blood pressure readings ranged as high as 250 systolic and 110-120 diastolic. Her serum potassium level was $1.8 \mathrm{mEq} / 1$ and her $\mathrm{EKG}$ showed the changes of hypokalemia. She was started on antihypertensive drugs and transferred to the University of Michigan Hospital.

After admission to the University Hospital her significant findings were blood pressure 220/110, serum sodium $143 \mathrm{mEq} / \mathrm{l}$, potassium $2.5 \mathrm{mEq} / \mathrm{l}$, bicarbonate $34 \mathrm{mEq} / 1$, creatinine $1.0 \mathrm{mg} / 100 \mathrm{ml}$, and hemoglobin $10.1 \mathrm{~g} / 100 \mathrm{ml}$. Further laboratory studies showed urinary aldosterone $371 \mathrm{mcg} / 24 \mathrm{hr}$ collection; serum aldosterone was $180 \mathrm{ng} / 100 \mathrm{ml}$; serum cortisol and urinary 17 -OHCS were normal $x$ 4. Plasma renins were measured by radioimmunoassay after salt loading and after Lasix ${ }^{\circledast}$ or low salt intake on December 16,17, 18, and 19 and were $0.2,0.4,0.4,0.3$, and $0.3 \mathrm{ng} / \mathrm{ml}$ per $\mathrm{hr}$, respectively. All of these renin measurements were considered very low and consistent with the diagnosis of primary hyperaldosteronism.

A CT scan of abdomen showed an $11 \times 10 \times 7$ $\mathrm{cm}$ right adrenal mass that was solid but not homogeneous. It displaced the inferior vena cava anteriorly (Fig. 5). After dexamethasone suppression an NP-59 scan showed abnormal uptake by the right adrenal mass with minimal uptake by the left adrenal.

On January 4,1985 , the patient was taken to the operating room with a diagnosis of probable adrenocortical carcinoma causing primary hyperaldosteronism. An anterior abdominal approach was used. The large right adrenal tumor could be separated from the anteriorly displaced inferior vena cava. However, the central adrenal vein contained a tumor thrombus. Because of this a small wedge of caval wall at the entry of this vein was excised and oversewn; there was no extension of tumor into the cava.

There was an anterior extension of the tumor into Glisson's capsule so that the undersurface of the right lobe of the liver was resected with gross total removal of the large tumor. There was no evidence of metastases to liver or to lymph nodes. At completion of the procedure it was the surgeon's opinion that all gross tumor had been removed.

The adrenal measured $11 \times 9 \times 4.5 \mathrm{~cm}$ and weighed $280 \mathrm{~g}$ on pathologic examination. It was soft and partly necrotic grossly. Histologically, the pattern was mostly solid or sheet-like and consisted of a great majority of compact cells. There were small foci of reticular pattern growth and perhaps 
Table 2. Primary hyperaldosteronism caused by adrenocortical carcinoma (preoperative clinical data).

\begin{tabular}{lllll}
\hline & $\begin{array}{l}\text { Duration } \\
\text { (symptoms) }\end{array}$ & $\begin{array}{l}\text { Blood } \\
\text { pressure }\end{array}$ & $\begin{array}{l}\text { Conn's } \\
\text { syndrome }\end{array}$ & Other symptoms \\
\hline Patient $1(41 \mathrm{~W} \mathrm{M})^{a}$ & $4 \mathrm{mo}$ & $270 / 140$ & Yes & Blurred vision \\
Patient 2 $(42 \mathrm{~W} \mathrm{M})$ & $2 \mathrm{yr}$ & $180 / 110$ & Yes & Syncope; claudication \\
Patient 3 $(54 \mathrm{~W} \mathrm{~F})^{b}$ & $4 \mathrm{mo}$ & $250 / 120$ & Yes & Headache \\
\hline
\end{tabular}

${ }^{a} \mathbf{W} \mathbf{M}=$ white male.

${ }^{b} \mathrm{~W} F=$ white female.

$1 \%$ of the cells had clear cytoplasm. There were large areas of necrosis and 4 mitoses per 20 highpower fields. There were focal areas of capsular invasion but no invasion into the liver parenchyma.

A diagnosis of adrenal cortical carcinoma was made. After the operation the patient's course was satisfactory for 3 weeks until she developed thrombophlebitis. At that time she was undergoing extensive evaluation for possible metastatic disease. The phlebitis was treated with heparin and Coumadin ${ }^{\circledR}$ and resolved. On February 7, 1985, the follow-up serum aldosterone level was $4.4 \mathrm{ng} / 100 \mathrm{ml}$ in contrast to $180 \mathrm{ng} / 100 \mathrm{ml}$ before the operation (normal range $3.0-10 \mathrm{ng} / 100 \mathrm{ml}$ ) and the urinary aldosterone level was $7.3 \mathrm{mcg} / 24 \mathrm{hr}$ collection in contrast to $371.2 \mathrm{mcg} / 24 \mathrm{hr}$ volume before the operation. An NP-59 scan obtained after dexamethasone suppression revealed no uptake on the right side and minimal uptake in the left adrenal gland.

The patient was started on mitotane $3 \mathrm{~g} / \mathrm{day}$ as prophylactic treatment of adrenal cortical carcinoma, but she tolerated this quite poorly with nausea, vomiting, and diarrhea and the drug was discontinued prior to discharge February 9, 1985. During the subsequent 6 months, blood pressure, and potassium and aldosterone levels remained normal with no evident recurrence of tumor. In July, 1985, blood pressure was $134 / 86$, serum potassium $3.9 \mathrm{mEq} / 1$, and urinary aldosterone 12 $\mathrm{mcg} / 24 \mathrm{hr}$.

\section{Discussion}

Adrenal cortical carcinomas that produce only mineralocorticoids such as aldosterone and deoxycorticosterone are rarely observed. The usually functional adrenal cortical carcinomas most frequently present with Cushing's syndrome (50\%), virilism (30\%), and feminization (12\%) [3].

In the same year (1955) that Conn [1] described the syndrome of primary hyperaldosteronism, Foye and Feichtmeir [4] reported an early example of adrenal cortical cancer "producing solely mineralocorticoid effect." In the 3 decades since this initial description of the syndrome of primary aldosteronism caused by adrenocortical carcinoma, a small number of isolated case reports of adrenal cortical carcinoma with mineralocorticoid excess have appeared in the literature.

In 1974, Stone and associates [5] collected 19 patients from the medical literature who had adrenal carcinoma associated with hypertension and hypokalemia and caused by mineralocorticoid excess. The majority of these patients exhibited the severe manifestations of hyperaldosteronism. The authors presented an analysis of the reported cases and added a case of their own. In contrast to the report of Salassa et al. [6] in 1983, Stone and associates [5] found that all of these reviewed cases demonstrated evidence of elevated levels of multiple steroid hormones "including aldosterone, deoxycorticosterone, 17-hydroxycorticosterone, 17ketosteroids and free corticoids." These authors suggested that in some of these cases with modest elevations of aldosterone, other nonmeasured steroids could have accounted for the apparent manifestations of hyperaldosteronism. It was suggested also that deoxycorticosterone could produce hypertension and hypokalemia when hyperaldosteronism is not present. Stone and associates [5] concluded from their study that a more appropriate designation for the cases reported as primary aldosteronism secondary to adrenal cortical carcinoma might be the broader one of "primary mineralocorticoid excess."

We cannot disagree with this conclusion. Adrenal cortical carcinomas are usually capable of producing multiple steroidal hormonal elements and precursors, both biologically active and inactive. In the 3 patients with adrenal cortical carcinomas of our study, however, the syndrome of primary hyperaldosteronism seems clearly evident. Tables 2 and 3 summarize some of the pertinent clinical and laboratory data that support the diagnosis of Conn's syndrome in each of our 3 patients. None of these patients had clinical or biochemical evidence of elevated cortisol or metabolites in blood or urine. Dexamethasone suppression (low dose) was normal in cases 1 and 3 and was not done in case 2 . Case 3 in our group of patients also had a preoperative elevation of deoxycorticosterone of $33 \mathrm{ng} / 100 \mathrm{ml}$ (normal 2-13 ng/100 ml). 
Table 3. Primary hyperaldosteronism caused by adrenocortical carcinoma (preoperative laboratory findings).

\begin{tabular}{llllr}
\hline & $\begin{array}{l}\text { Plasma } \\
\text { potassium } \\
(\mathrm{mEq} / \mathrm{l})\end{array}$ & $\begin{array}{l}\text { Plasma } \\
\text { aldosterone } \\
(\mathrm{ng} / 100 \mathrm{ml})\end{array}$ & $\begin{array}{l}\text { Plasma renin } \\
(\mathrm{ng} / \mathrm{ml} / \mathrm{hr})\end{array}$ & $\begin{array}{l}\text { Urinary } \\
\text { aldosterone } \\
(\mathrm{mcg} / 24 \mathrm{hr})\end{array}$ \\
\hline Patient 1 & 1.9 & 86 & 0.1 & 50 \\
Patient 2 & 2.3 & 24 & 0.3 & 36 \\
Patient 3 & 1.8 & 180 & 0.2 & 371 \\
\hline
\end{tabular}

Unfortunately, our patients did not have the full panoply of adrenocortical hormonal and precursor measurements with kinetic studies as conducted by Arteaga et al. [7] in their 1984 report of 3 patients with adrenal carcinomas and a similar syndrome. Unless such measurements are quite complete, interpretations will necessarily be incomplete and conclusions inaccurate.

The variability of histologic pattern found in these 3 cases of adrenal carcinoma is characteristic of those for aldosterone-producing carcinomas previously documented. The smallest tumor (case 2) is similar to that in the case reported by Foye and Feichtmeir [4] which metastasized widely. The largest neoplasm (case 3 ) is similar to most adrenocortical carcinomas [8], and that in case 1 has the broad trabecular and alveolar pattern with prominent vascular channels apparently unique to aldosteroneproducing malignant neoplasms [2]. This last pattern is described only in aldosterone-producing malignancies [8], while the other histologic features may be seen in other adrenocortical carcinomas.

\section{Résumé}

Depuis que le syndrome d'hyperaldostéronisme primitif a été décrit par Jerôme Conn en 1955 plus de 300 sujets qui en étaient victimes ont été identifiés à la Vanderbilt University de Nashville et à l'University of Michigan de Ann Arbor. La cause la plus fréquente de cette endocrinopathie répond à un adénome solitaire de la cortico-surrénale (72\%) alors que l'hyperplasie corticale des 2 surrénales est plus rarement à son origine $(27 \%)$, les adénomes multiples et/ou bilatéraux étant rarissimes (1\%). Au cours des 4 dernières années 3 cas d'hyperaldosteronisme dû à un cancer de la cortico-surrénale ont été observés dans les 2 centres. Chacun de ces cas exceptionnels est exposé cependant que la littérature récente concernant l'hyperalderosteronisme est analysée.

\section{Resumen}

Desde la descripción del síndrome de hiperaldosteronismo primario por Jeremo Conn en 1955, más de 300 pacientes con esta entidad han sido identificados en nuestros 2 centros médicos, la Universidad de Vanderbilt (Nashville) y la Universidad de Michigan (Ann Arbor). La causa más frecuente de esta endocrinopatía ha sido el adenoma solitario de la corteza suprarrenal (72\%); la hiperplasia adrenocortical bilateral ha sido la causa del hiperaldosteronismo primario en $27 \%$ de los casos; con menor frecuencia se han presentado los adenomas múltiples y/o bilaterales (1\%). En los 4 últimos años hemos encontrado 3 pacientes con hiperaldosteronismo primario comprobado bioquímicamente producido por carcinoma adrenocortical. Se presenta cada uno de estos casos poco usuales junto con una revisión de la literatura reciente.

\section{References}

1. Conn, J.W.: Primary aldosteronism: A new clinical syndrome. J. Lab. Clin. Med. 45:3, 1955

2. Symington, T.: Functional Pathology of the Adrenal Gland. Edinburgh, E.S. Livingston, 1969, pp. 145-148

3. Mostof, F.K., Davis, C.J., Jr.: Pathology of urologic cancer. In Principles and Management of Urologic Cancer, Chapter 3, N. Jaradpour, editor. Baltimore, The Williams and Wilkins Co., 1979, p. 56

4. Foye, L.V., Jr., Feichtmeir, T.V.: Adrenal cortical carcinoma producing solely mineralocorticoid effect. Am. J. Med. 19:966, 1955

5. Stone, N.N., Janoski, A., Muakkassa, W., Shpritz, L.: Mineralocorticoid excess secondary to adrenal cortical carcinoma. J. Urol. 132:962, 1984

6. Salassa, R.M., Weeks, R.E., Northcutt, R.C., Carney, J.A.: Primary aldosteronism and malignant adrenocortical neoplasia. Trans. Am. Clin. Climatol. Assn. 86:163, 1974

7. Arteaga, E., Biglieri, E.G., Kater, C.E., Lopez, J.M., Schambelan, M.: Aldosterone-producing adrenocortical carcinoma. Ann. Intern. Med. 101:316, 1984

8. Page, D.L., DeLellis, R.A., Hough, A.J., Jr.: Tumors of the adrenal. Washington, D.C., AFIP and UAREP (in press) 